\title{
Plasma cells with hairy projections and Auer rod-like inclusions in a patient with multiple myeloma
}

\author{
Praveen Sharma, ${ }^{1}$ Man Updesh Singh Sachdeva, ${ }^{1}$ Jasmina Ahluwalia, ${ }^{1}$ \\ Pankaj Malhotra ${ }^{2}$
}

'Department of Hematology, Post Graduate Institute of Medical Education and Research, Chandigarh, India ${ }^{2}$ Department of Medicine, Postgraduate Institute of Medical Education and Research, Chandigarh, India

\section{Correspondence to}

Dr Man Updesh Singh Sachdeva, drmanupdeshpgi@yahoo.co.in

Accepted 21 July 2017

\section{DESCRIPTION}

A 38-year-old woman presented to the outpatient clinic with complaints of easy fatiguability and bone pains for 1 month. On investigating, she was found to have plasma cell (PC) neoplasm of IgA-kappa type with 91\% PCs in bone marrow and $5 \%$ in peripheral blood (PB). Apart from PCs with classical morphology, there were PCs with distinct circumferential hairy cytoplasmic projections (figure 1) and a few others showing bulbous projections (figure 2). Bone marrow showed Auer rod-like inclusions in some of the PCs (figure 3) and rare histiocytes showing ingested Auer-rod like inclusions (figure 4). She was given two-drug combination chemotherapy (thalidomide and dexamethasone) because of financial limitation. During the second cycle of chemotherapy, she developed generalised weakness and shortness of

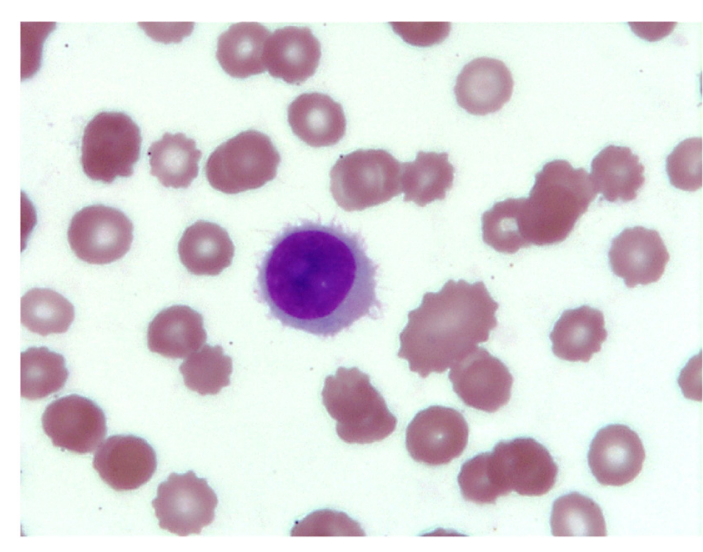

Figure 1 Circulating PC with distinct circumferential hairy projections (Leishman stain $\times 400$ ). PC, plasma cell.

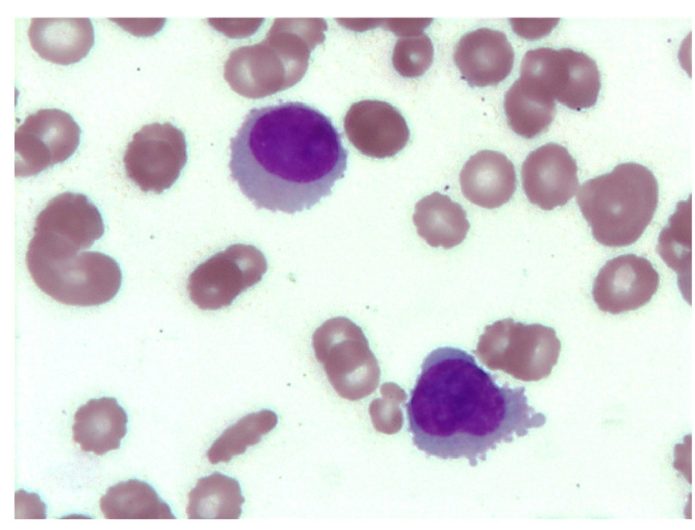

Figure 2 Few other PCs showing cytoplasmic blebs (Leishman stain $\times 400)$. PCs, plasma cells.

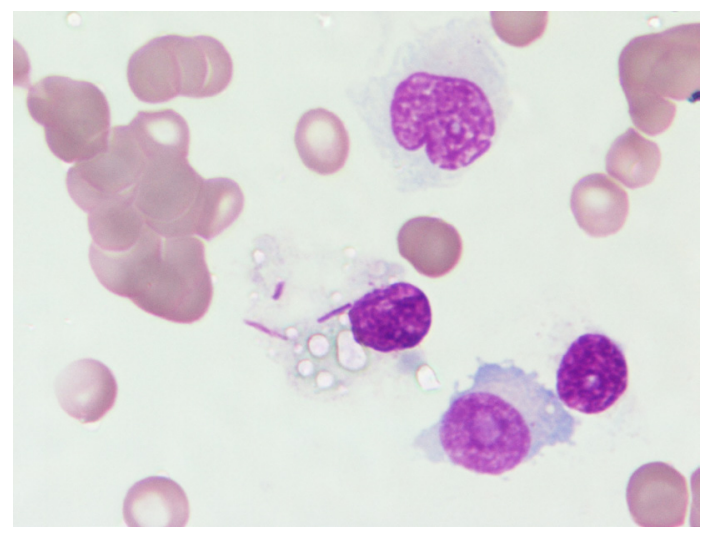

Figure 3 Bone marrow showing a PC with Auer rod-like inclusions (May-Grunwald Giemsa ×400). PC, plasma cell.

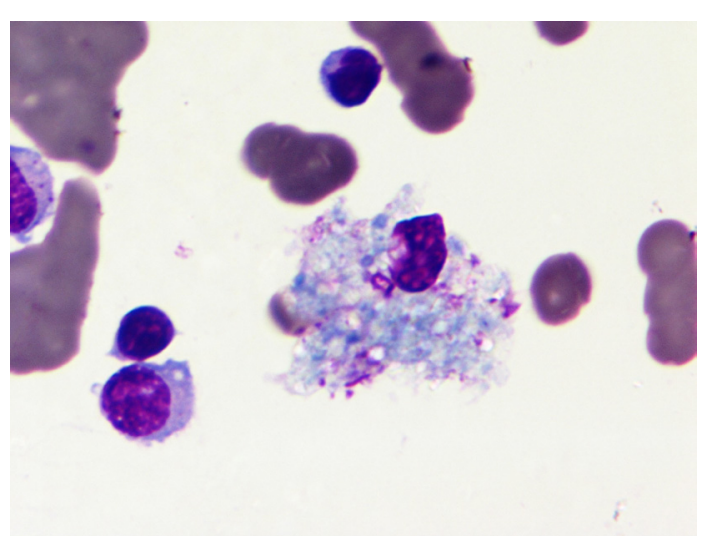

Figure 4 Bone marrow showing a histiocyte with ingested Auer rod-like inclusions and cellular debris (MayGrunwald Giemsa ×400).

breath. At this point, the PB smear revealed 27\% PCs with cells having hairy projections. Flow cytometry revealed these cells to have immunophenotype of aberrant PCs (positive for CD38, CD138, CD200, CD28 and $\operatorname{dim}$ CD45 with cytoplasmic $\kappa$ light-chain restriction and negative for CD19, CD56, CD81 and CD27), consistent with PC leukaemia. Triple-drug combination chemotherapy (cyclophosphamide, bortezomib and dexamethasone) was started and the patient improved. Currently, she is receiving eighth cycle of chemotherapy with a very good partial response.

PC leukaemia with hairy projections on PCs can masquerade as hairy cell leukaemia and can be morphologically misleading. ${ }^{1}$ However, ancillary techniques like flow cytometry help resolve 
such confusion with specific immunophenotypic characteristics. PCs with Auer-rod like inclusions are rarely described and although these inclusions demonstrate a close relationship with the Auer rods of myeloid cells, it is proven that the inclusions in PCs are composed of typical PC lyzosomal enzymes such as acid phosphatase, $\alpha-\mathrm{N}$-esterase or $\beta$-glucuronidase rather than

\section{Learning points}

- Plasma cells can have protean morphology including cytoplasmic hairy projections which a haematopathologist must be aware of, and this case emphasises that plasma cell leukaemia should be considered in the morphological differential diagnosis of hairy cell leukaemia. Ancillary techniques help significantly avoid misdiagnosis in cases where morphology is misleading.

- Plasma cells can have Auer-rod like inclusions, which are crystalline deposits of lyzosomal enzymes and completely different from intracytoplasmic immunoglobulin crystals. They are postulated to correlate with k-chain myelomas and adult Fanconi syndrome; however, their exact prognostic relevance is yet to be established. myeloperoxidase or chloroacetate esterase of myeloid cells. ${ }^{2}$ Although the prognostic information of the presence of such Auer-rod like inclusions is not exactly determined, they are correlated with $\kappa$-chain myelomas and adult Fanconi syndrome. ${ }^{3}$ A correlation with the former was noted, however, adult Fanconi syndrome was not seen in the index case.

Contributors PS: preparation of the manuscript and acquisition of data. JA and MUSS: idea and final approval of manuscript, reported the case and involved in workup of the case. PM: provided the clinical data, follow up of the patient and approved the manuscript.

Competing interests None declared.

Patient consent Obtained.

Provenance and peer review Not commissioned; externally peer reviewed.

(c) BMJ Publishing Group Ltd (unless otherwise stated in the text of the article) 2017. All rights reserved. No commercial use is permitted unless otherwise expressly granted.

\section{REFERENCES}

1 Kumar TN, Krishnamani K, Gandhi LV, et al. Plasma cell leukaemia masquerading as hairy cell leukaemia: a case report. Indian J Hematol Blood Transfus 2014;30:33-5.

2 Metzgeroth G, Back W, Maywald 0, et al. Auer rod-like inclusions in multiple myeloma. Ann Hematol 2003;82:57-60.

3 Hütter G, Nowak D, Blau IW, et al. Auer rod-like intracytoplasmic inclusions in multiple myeloma. A case report and review of the literature. Int J Lab Hematol 2009:31:236-40.

Copyright 2017 BMJ Publishing Group. All rights reserved. For permission to reuse any of this content visit http://group.bmj.com/group/rights-licensing/permissions.

BMJ Case Report Fellows may re-use this article for personal use and teaching without any further permission.

Become a Fellow of BMJ Case Reports today and you can:

- Submit as many cases as you like

- Enjoy fast sympathetic peer review and rapid publication of accepted articles

- Access all the published articles

- Re-use any of the published material for personal use and teaching without further permission

For information on Institutional Fellowships contact consortiasales@bmjgroup.com

Visit casereports.bmj.com for more articles like this and to become a Fellow 